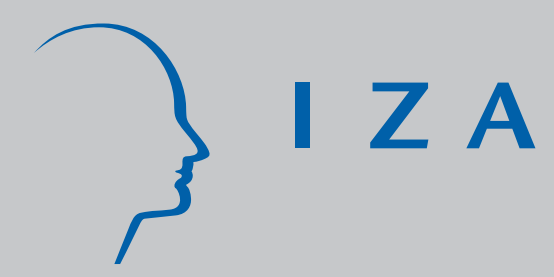

IZA DP No. 3826

Parental Marital Disruption, Family Type, and Transfers to Disabled Elderly Parents

Liliana E. Pezzin

Robert A. Pollak

Barbara Steinberg Schone

November 2008 


\title{
Parental Marital Disruption, Family Type, and Transfers to Disabled Elderly Parents
}

\author{
Liliana E. Pezzin \\ Medical College of Wisconsin \\ Robert A. Pollak \\ Washington University in St. Louis \\ and IZA \\ Barbara Steinberg Schone \\ Agency for Healthcare Research and Quality \\ and Georgetown University
}

Discussion Paper No. 3826

November 2008

\author{
IZA \\ P.O. Box 7240 \\ 53072 Bonn \\ Germany \\ Phone: +49-228-3894-0 \\ Fax: +49-228-3894-180 \\ E-mail: iza@iza.org
}

\begin{abstract}
Any opinions expressed here are those of the author(s) and not those of IZA. Research published in this series may include views on policy, but the institute itself takes no institutional policy positions.

The Institute for the Study of Labor (IZA) in Bonn is a local and virtual international research center and a place of communication between science, politics and business. IZA is an independent nonprofit organization supported by Deutsche Post World Net. The center is associated with the University of Bonn and offers a stimulating research environment through its international network, workshops and conferences, data service, project support, research visits and doctoral program. IZA engages in (i) original and internationally competitive research in all fields of labor economics, (ii) development of policy concepts, and (iii) dissemination of research results and concepts to the interested public.
\end{abstract}

IZA Discussion Papers often represent preliminary work and are circulated to encourage discussion. Citation of such a paper should account for its provisional character. A revised version may be available directly from the author. 
IZA Discussion Paper No. 3826

November 2008

\section{ABSTRACT}

\section{Parental Marital Disruption, Family Type, and Transfers to Disabled Elderly Parents}

This paper examines the family variables that affect intergenerational living arrangements and adult children's time and cash transfers to their unpartnered disabled elderly parents. The family variables we examine include parental marital status, parental marital history, whether the index child is a step child or a biological child of the parent, and whether the index child's siblings are step children or biological children of the parent. Using data from the Health and Retirement Studies - Asset and Health Dynamics Among the Oldest Old (HRSAHEAD) surveys, we estimate the joint probabilities that an adult child provides time and/or cash transfers to a parent and analyze a five-level categorical variable capturing parent-child living arrangements. Parameter estimates suggest significant detrimental effects of parental divorce and step relationship on time transfers and on the probability of coresidence with the index child. The composition of the index child's sibling network also affects transfers and living arrangement choices of adult children. Our findings suggest that demographic changes are weakening the traditional role of the family as a support network. Because more recent cohorts of elderly persons have experienced substantially higher rates of divorce, remarriage, and step parenthood than the cohort considered in this study, our findings raise concerns about the future availability of family care.

JEL Classification: $\quad 110, \mathrm{~J} 14$

Keywords: intergenerational transfers, aging, long-term care, family

Corresponding author:

Robert A. Pollak

Washington University

Olin Business School

Department of Economics

Campus Box 1133

1 Brookings Drive

St. Louis, MO 63130

USA

E-mail:pollak@wustl.edu

\footnotetext{
* This paper is forthcoming in the Journal of Gerontology: Social Sciences. The views expressed in the paper are those of the authors. No official endorsement by the Agency for Healthcare Research and Quality or the Department of Health and Human Services is intended or should be inferred. The authors gratefully acknowledge the financial support of the National Institute on Aging under grants 1 R01 AG24049 and R01 AG025475.
} 


\section{INTRODUCTION}

Divorce has become an important part of life for many in the United States. It has been estimated that nearly one half of all marriages will end in divorce (Kreider and Fields 2002; Martin and Bumpass 1989; Stevenson and Wolfers 2007). Overall, 45 percent of children are predicted to experience the break up of their parents' marriage by the age of 18 (Bumpass and Rindfuss 1979). One-third of all children will eventually live with a step parent before they reach adulthood (Glick 1989; Furstenberg and Cherlin 1991) and approximately 52 percent of children lived with both parents in 1998 compared to 73 percent in 1972 (Smith 1999). As a consequence of the increasing incidence of divorce and nonmarital childbirth, and subsequent (re)marriage, the traditional nuclear family — husband, wife and their joint children — is rapidly being replaced by new, more complex family structures. ${ }^{1}$ Conventional wisdom teaches that living in nontraditional families has profound negative effects on adults and children, although the scholarly literature is often cautious about the extent to which observed correlations reflect underlying causal mechanisms. A substantial literature within the social sciences has focused on the relationship between nontraditional family structures and outcomes for children (Cherlin et al. 1991; Duncan and Hoffman 1985; Furstenberg and Cherlin 1991; Furstenberg et al. 1983; McLanahan and Sandefur 1994; Haveman and Wolfe 1995; Morrison and Cherlin 1995; Seltzer and Bianchi 1998; Painter and Levine 2000; Ginther and Pollak 2004). A smaller literature has focused on the relationship between marriage or divorce and the well-being of adult men and

1 We use the Census definition of a traditional nuclear family to refer to families " in which a child lives with two married biological parents and with only full siblings if siblings are present." 
adult women (Waite 1995, Waite and Gallagher 2000). Relatively little is known, however, about the relationship between nontraditional family structures and adult children's transfers to their disabled elderly parents.

One particularly policy-relevant aspect of intergenerational relations that may be adversely affected by family disruption is care of disabled elderly parents. Intergenerational transfers are a prominent feature of the economic landscape with intra- and inter-household transfers often used to fulfill families' insurance roles: For disabled elderly persons, informal caregiving by adult children (i.e., the provision of services on a nonpaid basis) and intergenerational coresidence represent critical modes of assistance (McGarry and Schoeni 1997). Recent evidence suggests that adult children's involvement in parental care has declined over the past several decades (Kotlikoff and Morris 1990; Spillman and Pezzin 2000). Dramatic changes in family structure since the 1970 s - most notably the relative erosion of the traditional nuclear family - may be a factor in the decline in family caregiving.

Concerns about the growing elderly population and the potential erosion of family support have prompted researchers to begin examining the long-term effects of marital disruption. To a large extent, research has focused on the effects of marital disruption by examining the role of divorce and remarriage on the extent and quality of intergenerational relations (Altonji, Hayashi and Kotlikoff 1996; Aquilino 1994; Cooney and Uhlenberg 1990; Eggebeen 1992; Furstenberg, Hoffman and Shrestha 1995; Lye et al. 1995; Pezzin and Schone 1999). The general consensus is that divorce reduces family support and the quality of relations between adult children and their parents. Although the impact of divorce on bonds between adult children and their parents is stronger for fathers than for mothers (Furstenberg, Hoffman and 
Shrestha 1995), the quality of relations between divorced mothers and their children is generally lower than that between mothers and children in traditional nuclear families (Johnson 1989). Research also suggests that remarriage further weakens the bond between generations (Cooney and Uhlenberg 1990; White 1994; Pezzin and Schone 1999).

Researchers have recently turned their attention to the effects of marital disruption on transfers to elderly parents. Evidence is beginning to accumulate that disabled elderly parents in families that include at least one step child receive lower levels of transfers from their children than parents in traditional nuclear families (Pezzin and Schone 1999; Pezzin and Schone 2001; Lin 2008).

This study contributes to the growing literature on the effects of marital disruption, family structure and step relationships on intergenerational living arrangements and adult children's time and cash transfers to their disabled elderly parents. Our analysis differs from previous research in two important respects: First, we focus on the network of adult children of disabled elderly parents. Because caregiving patterns are the result of decisions made by all children in the network, the entire network is the appropriate unit of analysis. By examining transfers by adult children, we hope to understand the mechanism whereby parents who divorce, remarry, or have step children instead of or in addition to biological children might receive less support. Second, unlike previous research, which uses married elderly parents as the reference group, we investigate the effects of divorce, remarriage, family type and step children on transfers from adult children to their unpartnered elderly parents, using widowed parents as the reference group. The presence of a spouse or partner generally diminishes the caregiving role of children and weakens their incentives to provide assistance. Hence, unpartnered elderly persons 
(that is, those who are divorced, separated or widowed) are a group of particular policy interest because they are far more likely to live in a nursing home (Freedman 1996) and are also more likely to receive assistance from or coreside with their children than their married counterparts (Dwyer and Coward 1991). By focusing on children of unpartnered elderly parents, we are able to estimate the effects of divorce, remarriage, family type, and step relationship for a group of elderly individuals who, after controlling for their disability status, are likely to have similar needs for assistance.

\section{Marital Disruption, Family Structure and Transfers to Elderly Parents}

Researchers from a variety of social science disciplines have offered theories and conceptual perspectives to explain why divorce, remarriage and step relationships might negatively affect intergenerational relations. Sociologists, developmental psychologists and demographers have advanced the notion of attachment (Hazan and Shaver 1992), attribution (Grych and Fincham 1992), life course (Amato and Booth 1997; Furstenberg 1981; Rossi and Rossi 1990) and social capital (Coleman 1988) to explain the impact of marital dissolution on adults and children. Amato (2000) reviews the empirical literature on the consequences of divorce and provides an excellent synthesis of the theoretical perspectives. As Amato notes, a common theme underlying most of this literature is that marital disruption is a stressful life transition to which family members must adjust. The severity and duration of negative outcomes depend on the presence of and interaction between mediator (stressors) and moderator (protective) factors with successful adjustment among children often varying with contact and attachment to both the custodial and non-custodial parent (Amato 2000). 
Reciprocity is an important component in many of these theories. Interpersonal relationships are often depicted as yielding dividends as the recipient (in this case, the child) accumulates social obligations and expectations of repayment. To the extent that the rules of reciprocal caring are developed, learned and maintained by repeated contacts, it is thus plausible that discontinuities in family relationships caused by divorce may adversely affect intergenerational exchange.

A substantial body of economics literature has established that economic relationships within families are crucial determinants of the effectiveness of policy initiatives (Barro 1974; Becker 1981; Bernheim 1989; Lundberg and Pollak, 1993 and 1994). As a means of exploring the nature of implicit agreements between elderly parents and their adult children, economists have focused primarily on the motives for intergenerational transfers. The most prominent strand of this literature has posited intergenerational "altruism" as the motive for child-to-parent transfers. A second, and more controversial, strand of research has departed from the assumption of altruism and proposed "exchange" as the main motive for child-to-parent transfers (Bernheim, Shleifer and Summers 1985; Cox 1987; Cigno 1991; Cox and Rank 1992; Altonji, Hayashi and Kotlikoff 1992; Altonji, Hayashi and Kotlikoff 1997; Cox, Hansen and Jimenez 1996). Although the precise nature of the postulated exchange mechanism differs across studies, it generally reflects one of two notions: reciprocity, whereby transfers are made as a repayment for past parental transfers; or strategic behavior, whereby transfers are made in the hope of securing future parental transfers.

With respect to marital dissolution, economists argue that divorce reduces the resources devoted to children (Duncan and Hoffman 1985). As a consequence, children's consumption, 
health and human capital will be underprovided following divorce (Weiss and Willis 1985). Hence, when parents divorce, the altruistic and/or reciprocal ties between generations will be weakened. This weakening of ties is especially likely between children and non-custodial parents.

Contact and resource flows are likely to be further weakened when parents remarry. Remarriage creates a multitude of economic and social ties across households. Membership in blended families tends to be more fluid than in traditional nuclear families, and family roles are less clearly specified (Cherlin 1978; Furstenberg 1987). The increased complexity in family structure and household organization also increases the "transaction costs" - the costs involved in monitoring and enforcing implicit relational agreements within and across households-- likely leading to further reductions in transfers.

Although most researchers are concerned about the effects of rising rates of divorce and remarriage on the future of the family, a few researchers have rejected doom-and-gloom forecasts of declining support between generations based on these trends. For example, Wachter (1997) point out that if we include stepkin, the size of kin networks has not contracted; Amato has observed that "divorce, although temporarily stressful, represents a second chance at happiness for adults and an escape from a dysfunctional home environment for children" and that adults find fulfillment and children develop successfully in a variety of family structures (Amato and Keith 1991; Logan and Spitze 1996; Amato 2000). Despite looser norms about roles of members in step and blended families, remarriage may promote interactions between parents and their acquired step children, positively influencing the degree of reciprocity shared by step generations and increasing the kin supply available to elderly parents as they age and require assistance 
(Curran, McLanahan and Knab 2003). Evidence is lacking, for example, on whether changes within the family and the consequent restructuring of kinship ties following marital disruption have led to shifts in patterns of time and cash transfers to elderly parents. In what follows, we provide new evidence of the effects of parental divorce and remarriage on adult children's decisions to provide care to frail elderly parents and examine how siblings network composition affects the long-term care behavior of its individual members.

\section{DATA AND METHODS}

Data for this analysis are drawn from matched observations from waves one and two of the Assets and Health Dynamics of the Elderly (AHEAD) survey. The AHEAD survey is an ongoing stratified panel survey that began with a nationally-representative sample of communitybased persons aged 70 and older in 1993 from the United States. Respondents are followed longitudinally roughly every two years. A total of 8,219 respondents, corresponding to 6,052 households, were interviewed in wave one of AHEAD (AHEAD1), the data source of all independent variables. Data from wave two of AHEAD (AHEAD2), collected in 1995 and the source of our outcome variables, include re-interviews of 6,948 elderly persons (attrition due to death and interview non-response accounted for 9.6 percent and 5.8 percent, respectively, of sample size loss between waves one and two).

For the purpose of our analysis, we limited our sample to AHEAD respondents who reported in wave two their marital status as widowed or as divorced/separated (AHEAD does not distinguish between divorce and separated), who reported at least one living child, and who reported having difficulty with at least one basic or instrumental activity of daily living. The 
basic activities of daily living (ADLs) are transferring, dressing, bathing, toileting, eating, and walking across a room; instrumental activities of daily living (IADLs) are grocery shopping, preparing meals, taking medications, using a telephone, and managing household finances. Since the unit of analysis in our study is the network of adult children, we exploited the sibling structure of the AHEAD data and formed individual records for each of the 4,863 children associated with the 1,593 elderly parents meeting our inclusion criteria.

\section{Variable Definitions}

The dependent variables we examine in this study are intergenerational living arrangements and cash and time transfers provided by adult children to their elderly parents. We represent living arrangements with a five-level categorical variable indicating whether the parent lives (i) with the index child i; (ii) with another child; (iii) with other relatives or non-relatives; (iv) in a nursing home or (v) alone (reference category). A child was coded as providing time transfers to the parent if the elderly respondent identified that child as providing assistance with one or more ADLs or IADLs in the past four weeks; zero otherwise. Finally, our measure of cash transfers was based on the elderly parent's report that a child provided financial assistance greater than $\$ 500$ to the parent in the past two years.

Of primary interest for our analysis are variables that represent family type and how the index child is related to the parent (biological child or step child). We introduce the term "family type" to denote the composition of the index child's sibling network (i.e, the kin relationship between the index child's siblings and the parent) and to distinguish it from the familiar notion of family structure, which is prominent in discussions of outcomes for children (Ginther and Pollak, 


\section{9}

2004). Our definition of family type characterizes the index child's sibling network according to the presence or absence of other biological or step children of the parent. Specifically, we create two variables that identify (a) index children whose sibling network includes at least one step child of the parent and (b) index children whose sibling network includes at least one biological child of the parent. We also include a variable reflecting whether the index child is a biological or a step child. Finally, we include an interaction term between the index child's relationship to the parent and the presence of step children in the sibling network; we do this to identify potentially differential effects for biological children in blended families relative to biological children in traditional nuclear families."

All of our models include a rich set of control variables to capture differences across adult children and their elderly parents along a number of dimensions: demographic and economic characteristics of the parent; parental health and functioning; and demographic and economic characteristics of the index child and the child's sibling network. In addition to basic demographic characteristics (age, race, gender, and education), we include two variables to measure parental marital history: the parent's current marital status (currently divorced; reference category is currently widowed) and an indicator of whether the parent has experienced at least one remarriage. Parental economic status is incorporated into the analysis by two constructs: current, nonbequeathable income (the sum of Social Security and pension income) and bequeathable wealth, (the parent's total net worth). Parental health is captured by the inclusion of two indicators based on severity of disability (parents with: 1 or 2 ADLs; 3 or more ADLs; both relative to parents who are limited on IADLs only). Finally, the economic status of children is represented by two indicator variables that reflect the economic well-being of children relative to 
the parent: (i) whether the index child is financially worse off than the parent respondent and (ii) whether all siblings of the index child are worse off than the parent respondent (AHEAD asks the parent respondent about each child's financial status relative to her own but does not collect any additional information about the income and wealth of the children). Table 1 contains a complete list of variable definitions and summary information for our sample.

\section{Empirical Strategy}

Our empirical goal is twofold. First, we are interested in examining whether parental marital disruption, child-parent kin relationship, and family type affect the likelihood that an adult child makes time and cash transfers to a disabled elderly parent. Second, we wish to investigate the extent to which these variables influence the living arrangements of adult children and their elderly parents.

We use a bivariate probit specification to model jointly the probabilities that an adult child provides time $\left(T_{i j}\right)$ and/or cash transfers $\left(C_{i j}\right)$ to a parent. Specifically, for every child $i$ in family $j$, we estimate transfer equations of the form:

$$
\begin{aligned}
C_{i j}^{*} & =X_{i j} \alpha+Z_{i j} \beta++Y_{j} \delta+\zeta_{i j} \\
C_{i j} & =1 \text { if } C_{i j}^{*} \geq 0 \\
C_{i j} & =0 \text { if } C_{i j}^{*}<0 \\
T_{i j}^{*} & =X_{i j} \alpha^{\prime}+Z_{i j} \beta^{\prime}+Y_{j} \delta^{\prime}+\xi_{i j} \\
T_{i j} & =1 \text { if } T_{i}^{*} \geq 0 \\
T_{i} & =0 \text { if } T_{i}^{*}<0 . \\
\left(\zeta_{i j}, \xi_{i j}\right) & \sim N(0,1, \rho)
\end{aligned}
$$


where $X_{\mathrm{ij}}$ is a child-parent specific variable capturing the nature of their relationship (biological versus step); $Z_{\mathrm{ij}}$ is a vector of child-specific variables assumed to affect the adult child's willingness to provide transfers, including family size and type; and $Y_{j}$ is a vector of parentspecific variables (invariant within a family) capturing demographic, economic and health status factors assumed to affect the parent's need for transfers (parental race, marital status, marital history and disability level). We estimate the coefficients of the model $-\alpha, \beta, \delta, \alpha^{\prime}, \beta^{\prime}$ and $\delta^{\prime}-$ along with the correlation coefficient $\rho$.

Elderly respondents in our sample are observed in one of five distinct living arrangements (with the index child; with another child; with other relatives or non-relatives; in a nursing home; or alone). To estimate living arrangements, we use a multinomial logit specification. Formally, we assume that the value of living arrangement $k$ for the $i^{\text {th }}$ child in family $j$ is given by:

$$
L_{i j k}^{*}=X_{i j} \alpha_{k}^{t \prime}+Z_{i j} \beta_{k}^{t t}+Y_{j} \delta_{k}^{t+}+\varepsilon_{i j k} \quad k=1, \ldots, 5,
$$

where $X, Y$ and $Z$ are defined as above and $\alpha^{\prime \prime}, \beta^{\prime \prime}$ and $\delta^{\prime \prime}$ are the coefficients to be estimated. The predicted living arrangement is that which exhibits the highest latent value, $L_{i j k}=1$ if

$L^{*}{ }_{i j k}>L^{*}{ }_{i m} ; \forall m \neq k ; L_{i j k}=0$ otherwise.

Estimates of the bivariate probit transfer equations and the multinomial logit living arrangements are obtained via maximum likelihood. Because our data include observations on more than one child in multiple sibling families, we adjust the standard errors of our estimates to reflect the inherent correlation across observations. 


\section{RESULTS}

Table 2 presents summary information on cash and time transfers, as well as living arrangements, for the children in our sample. The first panel provides information on children's transfers by parental marital status and marital history. The next panel focuses on children's transfers by their relationship to the parent while the last panel shows children's transfers by family type.

The bivariate associations suggest that children are significantly less likely to provide care to their disabled parent if the parent is divorced (relative to care they would provide to a widowed parent). Divorced parents are less likely to coreside with the index child or any other children; they are also more likely to live alone or in a nursing home than widowed parents. The relationship between transfers, living arrangements and remarriage appears more modest: children with parents who remarried are less likely to provide cash transfers and more likely to have a parent who is in a nursing home.

Data from the mid-panel suggest considerable variation in transfers by the type of relationship (biological versus step) of the parent and child. The likelihood of cash as well as time transfers from biological children, for example, is about four-times that of step children. Consistently, results for living arrangements indicate that step children are significantly less likely to coreside with the parent (1.8 percent versus 7.9 percent $)$ and more likely to have a parent living alone or in a nursing home than biological children (63.6 percent versus 60.6 percent and 10.6 percent versus 7.5 percent, respectively).

The bottom panel of Table 2 provides information about family type. Distinguishing children by family type, we find that children in traditional nuclear families are significantly 
more likely to provide cash and time transfers than children in blended families (that is, families with step children). Similarly, index children of parents in blended families are less likely to coreside with the parent and slightly more likely to have their parent live with other relatives or non-relatives than index children in traditional nuclear families. These findings raise the possibility that a child's transfer behavior might depend not only on the relationship to the parent (i.e., biological or step), as proposed in the literature, but also on the composition of the sibling network. To investigate and isolate these effects, we turn to multivariate analyses which are discussed below.

Findings from these multivariate analyses are consistent with the univariate results discussed above, and indicate that the general pattern of lower transfers from step children and children of divorced parents persists despite the inclusion of a wide array of potential confounders. Table 3 presents estimated coefficients from the bivariate probit model of cash and time transfers and relative risk ratios from the multinomial logit model of living arrangements for children who have an unpartnered disabled elderly parent. The multivariate results indicate that step children are significantly less likely to provide cash or time transfers to their elderly parents; they are also significantly less likely to coreside with a parent (relative to the parent living alone). The estimates also suggest a detrimental effect of parental divorce on time transfers and on the probability of coresidence with the index child: children of divorced parents are about half as likely as children of widowed parents to coreside with a parent.

Turning to family type, the cash and time transfer estimates indicate that the presence of biological children in the index child's sibling network lowers the propensity to provide either type of transfer to the disabled elderly parent. The presence of step children, on the other hand, 
has no statistically significant effect on either cash or time transfers by the index child. Results from the living arrangement estimation are stronger. Controlling for family type, parental marital history and a variety of other socio-demographic and economic characteristics, we still find that step children are only ten percent as likely as biological children to coreside with a parent. Children whose sibling network includes at least one biological child of the parent are less likely to live with the parent or to have their parent live with other relatives or non-relatives (relative to living alone). The presence of biological children in the index child's sibling's network, however, increases by twelve times the odds that the parent lives with another child (as opposed to living alone). In contrast, biological children in blended families are significantly less likely to have a parent living with another child. Regardless of relationship and family type, a greater number of siblings reduces the likelihood that the index child coresides with the parent and increases the likelihood that the parent lives with another child. Family size is also associated with reduced odds of nursing home residence (relative to living alone).

Given the inherent difficulty in interpreting the underlying coefficients from the bivariate probit and multinomial logit models, particularly for interacted constructs, we calculate predicted probabilities of all outcomes for alternative child-parent relationship/family type combinations. These predicted probabilities, shown in Table 4, are computed by setting the relevant relationship and family type variables to new values while holding all other variables constant at their original levels. Predicted probabilities are calculated for each child and then averaged across the sample. Differences in the predicted probabilities across alternative relationship/family type groups can be interpreted as the marginal effects of the variables of interest on the outcomes. 
Overall, the predicted probabilities indicate that the incremental effect of being a step child relative to a biological child is substantial. Biological children with no siblings are predicted to be nearly four times more likely to make cash (13.5\% versus $2.9 \%)$ or time transfers (26\% versus $7.7 \%$ ) to the parent than single step children (Rows A and E of Table 4). Although there is relatively little difference in cash and time propensities among step children by sibling network characteristics (Rows $\mathrm{E}$ through $\mathrm{H}$ of Table 4), the results reveal a substantially higher likelihood of providing time transfers among biological children whose sibling network includes step children of the parent $(25.6 \%$, Row C) relative to biological children in traditional or blended families (15.1\%, Row B and 14.8\%, Row D, respectively). One plausible interpretation of this finding is that biological children may attempt to compensate for the (anticipated) lower involvement of siblings who are step children of the parent. The presence of other biological children, on the other hand, weakens this propensity by providing additional "viable" candidates to share in that responsibility (i.e., other biological children may take on some of the cash and time transfer responsibility).

The predictions also indicate that the addition of other biological children to a family with step children has a strong effect on living arrangements of biological children (Rows C and D of Table 4). The likelihood that the index biological child has a parent who lives with another child is twelve times greater-12.5\% in blended families with multiple biological children compared to $1 \%$ in blended families where only the index child shares a biological link with the parent. This increase is accompanied by a sizeable decrease in the probability that the parent lives with the index child (11.6\% to $7.8 \%)$ or with another relative or non-relative $(13.7 \%$ to $7.3 \%)$ and a somewhat smaller decrease in the likelihood that the parent lives alone $(67.3 \%$ to $64.3 \%)$. 
Overall, the lowest probability that the parent coresides with the index child occurs in blended families where the index child is a step child (Rows F and H). Parents are most likely to live alone when their only child is a step child (78.6\%, Row E) and most likely to be institutionalized when their family network is blended $(12.2 \%$, Row $\mathrm{H})$ or consists solely of step children $(11.7 \%$, Row G).

In addition to the effects of child-parent relationship, family type, and parental marital history, our remaining results in Table 3 suggest that children's decisions to provide financial or time transfers to their elderly parents are driven by a number of other factors. We observe that children are more likely to provide time transfers to older parents as well as to parents with higher levels of disability, a result likely capturing the child's response to the parent's need for care. Cash transfers, on the other hand, do not appear sensitive to these or most other parentspecific demographic and health variables (except for a higher propensity among black/African American children). Instead, we find children's cash transfers depend primarily on the parent's wealth, as measured by his or her net worth, and the child's relative financial status. Finally, our finding of a positive, albeit modest, correlation between the cash and time transfer equations may suggest that children in our sample do not view financial transfers as substitutes for time transfers. Alternatively, the positive correlation between cash and time assistance may reflect unobservable characteristics, such as the child's "giving disposition" or the parent's unobservable need (Soldo and Henretta 2007).

Lastly, results regarding parent and child living arrangements are generally consistent with expectations. Parental characteristics, such as disability level and race/ethnicity, affect living arrangements, as do competing demands on the child's time (marital status and the 
presence of children), the child's economic status, and the number of siblings in the index child's sibling network.

\section{DISCUSSION}

Aside from the growth in the elderly population, one of the most marked demographic trends of the twentieth century was the tremendous increase in divorce and remarriage. These trends have precipitated dramatic changes in family structure, a development that has captured the attention of researchers and policymakers concerned with the well-being of children. Relatively little research, however, has explored the effects of these demographic trends on transfers by adult children to their disabled elderly parents.

In this paper, we have examined the effects of divorce and remarriage on adult children's transfers of time and cash to disabled elderly parents as well as on the living arrangements of disabled elderly parents. In general, our results support the notion that family disruption, broadly conceived, has a negative impact on child-to-parent transfers. Our finding of a detrimental effect of parental divorce on children's transfers is consistent with the literature and suggests a growing number of elderly persons who will be particularly vulnerable in later life due to weaker ties to their children.

We also examine the independent effects of family type. We find strong evidence that step children are less likely than biological children to provide assistance across all outcomes. Contrary to expectations, however, the biological children of a parent who also has step children are no less likely than biological children of a parent who has no step children to transfer resources to their elderly parent. In fact, biological children whose sibling network includes only 
additional step children were significantly more likely than biological children in traditional nuclear families to provide care and to coreside with the parent — a result that might reflect their attempt to compensate for the limited involvement of step children. As indicated by our parentlevel analyses (Pezzin and Schone 1999), however, the offsetting behavior by biological children in these families does not compensate fully for the lower level of transfers by step children.

Historically, children's time transfers have been an important component of support to disabled elderly persons (Morgan 1984). Our findings that transfers from adult children to their elderly parents depend on parental marital status, kin relationship and, to a lesser extent, family type suggests that changing family patterns are altering the traditional role of the family as a support network. These findings raise concerns about future cohorts of elderly persons who will have experienced substantially higher rates of divorce, remarriage, and step parenthood than the AHEAD cohort considered in this study. Nonmarital fertility is also a concern. Because the AHEAD cohort has very low rates of nonmarital fertility, any attempt to use AHEAD to infer the effect of nonmarital fertility on family transfers would require very strong assumptions.

Evidence also suggests increased reliance on government subsidized formal care by elderly persons facing reduced informal care provided by their adult children (Spillman and Pezzin 2000). That evidence and our findings imply increased demands on public programs, such as Medicare and Medicaid, to fill in the gap resulting from lower levels of private transfers within these complex families. Of equal concern is the possibility that disabled elderly persons who are not eligible for public long-term care benefits and who cannot otherwise afford formal care will have their needs unmet. 
In addition to highlighting the complexities associated with defining and measuring family type, our study also indicates that much remains to be learned about family behavior and suggests several avenues for future exploration. Data limitations preclude investigating the dynamic processes underlying intergenerational relations. A notable limitation of the AHEAD surveys is the lack of information about the timing and nature of early family transitions. For example, the data do not allow us to distinguish step relationships that result from remarriage following widowhood from those that result from remarriage following divorce. We are also unable to ascertain directly the relationship among adult children (full siblings, half siblings or step siblings) or the alternative demands placed on step children who may be at risk for providing care to their own biological parents. Finally, we know little about the parents or sibling networks of the spouses of the adult children in our sample. Information about the timing of family transitions and the history of all members in the extended family would allow us to distinguish the potentially differential effects of the step relationships acquired through alternative processes and the effects of competing demands on transfers from biological children and step children. Such analyses require rich and complex data on the extended family, data that are currently unavailable.

Finally, research on the relationship between family type and transfers to elderly persons may shed some light on the motives for intergenerational transfers. Research examining the motives for late life child-to-parent transfers has generally ignored family type, implicitly assuming that elderly parents and adult children shared the economic and social stability of traditional nuclear families throughout their lives. Our results suggest the need to consider 
family type, in addition to divorce and remarriage, when constructing and estimating models of intergenerational transfers. 


\section{REFERENCES}

Altonji, J.G., Hayashi, F. \& Kotlikoff, L. (1996). The effects of income and wealth on time and money transfers between parents and children. NBER Working Paper no.5522.

Altonji, J., Hayashi F., \& Kotlikoff, L. (1992). Is the extended family altruistically linked? Direct tests using micro data. American Economic Review, 82, 1177-98.

Altonji, J., Hayashi F., \& Kotlikoff, L. (1997). Parental altruism and inter vivos transfers: theory and evidence. Journal of Political Economy, 105, 1121-1166.

Amato, P.R. (2000). The consequences of divorce for adults and children. Journal of Marriage and the Family, 62, 1269-1287.

Amato, P.R. \& Booth, A. (1997). A generation at risk: Growing up in an era of family upheaval. Cambridge: Harvard university Press.

Amato, P.R. \& Keith, B. (1991). Consequences of parental divorce for children's well-being: A meta-analysis. Psychological Bulletin, 110, 26-46.

Aquilino, W.S. (1994). Impact of childhood family disruption on young adult's relationships with parents. Journal of Marriage and the Family, 56, 295-313.

Barro, R. (1974). Are government bonds net wealth? Journal of Political Economy, 82, 10951117.

Becker, G. (1981). A treatise on the family. Cambridge: Harvard University Press.

Bernheim, B.D. (1989). Intergenerational altruism, dynastic equilibria and social welfare. Review of Economic Studies, 56, 119-28.

Bernheim, B. D., Shleifer, A. \& Summers, L. (1985). The strategic bequest motive. Journal of Political Economy, 93, 1045-76.

Bumpass, L.L. and R.R. Rindfuss (1979). Children's Experience of Marital Disruption. American Journal of Sociology 85, 49-65.

Cherlin, A. (1978). Remarriage as an incomplete institution. American Journal of Sociology, $84,634-650$.

Cherlin, A. (2004). The deinstitutionalization of American marriage. Journal of Marriage and Family, 66, 848-861. 
Cherlin, A., Furstenberg, F., Chase-Landsdale, P., Lindsay, P. (1991). Longitudinal studies of effects of divorce on children. Science, 252, 1386-89.

Cigno, A. (1991). Economics of the family. Oxford: Clarendon Press.

Coleman, J.S. (1988). Social capital in the creation of human capital. American Journal of Sociology, 94, S95-S120.

Cooney, T.M. \& Uhlenberg, P. (1990). The role of divorce on men's relations with their adult children after midlife. Journal of Marriage and the Family, 52, 677-688.

Cox, D. (1987). Motives for private income transfers. Journal of Political Economy, 95, 508-46.

Cox, D., Hansen, B. \& Jimenez, E. (1996). Are household altruistic? Private transfers in a laissez-faire economy. Working paper. Boston: Boston College.

Cox, D. \& Rank, M..(1992). Inter-vivos transfers and intergenerational exchange. Review of Economic and Statistics, 74, 305-14.

Curran, S.R., McLanahan, S. \& Knab, J. (2003). Does marriage expand perceptions of kinship among the elderly? Social Science Research, 32, 171-190.

Duncan, G.J. \& Hoffman, S.D. (1985). A reconsideration of the economic consequences of marital dissolution. Demography, 22, 485-497.

Dwyer, J.W. \& R.T. Coward. (1991). A multivariate comparison of the involvement of adult sons versus adult daughters in the care of impaired adults. Journal of Gerontology: Social Sciences, 46, S259-269.

Eggebeen, D.J. (1992). Family structure and intergenerational exchanges. Research on Aging, 14, 427-447.

Freedman, V.A. (1996). Family structure and the risk of nursing home admission. Journal of Gerontology: Social Sciences, 51B, S61-S69.

Furstenberg, F.F. 1987. The new extended family: the experience of parents and children after remarriage. In K. Pasley and M. Ihinger-Tallman (Eds.), Remarriage and stepparenting: current research and theory. NewYork: Guilford Press.

Furstenberg, F.F. (1994). History and current status of divorce in the United States. The Future of Children, 4, 29-43. 
Furstenberg, F.F. \& Cherlin, A.J. (1991). Divided families: what happens to children when parents part. Cambridge: Harvard University Press.

Furstenberg, F.F., Hoffman, S.D. \& Shrestha,L. (1995). The effect of divorce on intergenerational transfers: new evidence. Demography, 32, 319-333.

Furstenberg, F.F, Nord, C.W., Peterson, J.L., \& Zill,N. (1983). The life course of children of divorce. $\quad$ American Sociological Review, 48, 656-668.

Ginther, D.K. \& Pollak, R.A. (2004). Family structure and children's educational outcomes: blended families, stylized facts, and descriptive regressions. Demography, 41, 671-696.

Glick, P. (1989). Remarried families, stepfamilies, and step children: a brief demographic profile. Family Relations, 38, 24-27.

Grych, J.H. \& Fincham F. (1992). Marital dissolution and marital adjustement: An attributional analysis. In T.L. Orbuch (Ed.) Close relationship loss. NY: Springer-Verlag.

Haveman, R. \& Wolfe, B. (1995). Succeeding generations: on the effects of investments in children. New York: Russell Sage Foundation.

Hazan, C. \& Shaver, P. (1992). Broken attachments: Relationship loss from the perspective of attachment theory. In T.L. Orbuch (Ed.) Close relationship loss. NY: Springer-Verlag.

Johnson, C.L. (1989). Divorce-related changes in relationships" in J.A. Mancini (Ed.). Aging parents and adult children. Toronto: Lexington Books.

Kotlikoff, L.J. \& Morris, J. (1990). Why don't the elderly live with their children? in David A. Wise (Ed.), Issues in the Economics of Aging,. Chicago: University of Chicago Press.

Kreider, R.M. \& Fields, J.M. (2002). Number, timing, and duration of marriages and divorce: 1996. U.S. Census Bureau Current Population Reports.

Lin, I. (2008). Consequences of parental divorce for adult children's support for their frail parents. Journal of Marriage and Family 70(1), 113-128.

Logan J. \& Spitze, G. (1996). Family ties: enduring relations between parents and their grown children. Philadelphia: Temple University Press.

Lundberg, S. \& Pollak, R.(1993). Separate spheres bargaining and the marriage market. Journal of Political Economy, 101, 988-1010. 
Lundberg, S. \& Pollak, R. (1994). Noncooperative bargaining models of marriage. American Economic Review, 84, 132-37.

Lye, D.N., Klepinger, D.H., Hyle, P.D., \& A. Nelson, A. (1995). Childhood living arrangements and adult children's relations with their parents. Demography, 32, 261-280.

McGarry, K. \& Schoeni, R. (1997). Transfer behavior within the family: results from the asset and health dynamics survey. Journal of Gerontology: Social Sciences, 52B, 82-92.

McLanahan, S. \& Sandefur, G. (1994). Growing up with a single parent. Cambridge: Harvard University Press.

Martin, T. \& Bumpass, L.L. (1989). Recent trends in marital disruption. Demography, 26, 37-51.

Morgan, J. (1984). The role of time in the measurement of transfer and well-being. in Marilyn Moon (Ed.), Economic transfers in the united states: studies in income and wealth. Chicago: University of Chicago Press.

Morrison, D. \& Cherlin, A. (1995). The divorce process and young children's well-being: a prospective analysis. Journal of Marriage and the Family, 57, 800-12.

Painter, G. \& Levine, D. (2000). Family structure and youth's outcomes: which Correlations are causal? Journal of Human Resources, 34, 524-549.

Pezzin, L.E. \& Schone, B. (1999). Parental marital disruption and intergenerational transfers: an analysis of lone elderly parents and their children. Demography, 36, 287-297.

Pezzin, L.E. \& Schone, B. (2001). Exploring the theoretical foundations of altruism. In P.K. Chopra \& B.N. Ghosh (Eds.) Gender and development. England: Wisdom House Press.

Rossi, A. \& Rossi, P. (1990). Of human bonding: parent-child relations across the life course. New York: Aldine de Gruyter.

Seltzer, J.A. \& Bianchi, S.M. (1988). Children's contact with absent parents. Journal of Marriage and the Family, 50, 663-677.

Smith, T.W. (1999). The emerging $21^{\text {st }}$ century american family. National Opinion Research Center, University of Chicago, November 24.

Soldo, B.J. \& Henretta, J.C. (2007). Why do families differ from each other? Multi-generational transfers and parent care. Paper presented at the IZA Workshop on Long-Term Care. Bonn, Germany. 
Spillman, B.C. \& Pezzin, L.E. (2000). Potential and active family caregivers: changing networks and the sandwich generation. The Milbank Quarterly, 78, 347-374.

Stevenson, B. And J. Wolfers. 2007. "Marriage and Divorce: Changes and their Driving Forces" Journal of Economic Perspectives 21 (2):27-52.

Wachter, K. (1997). Kinship resources for the elderly. Philosophical Transactions: Biological Sciences, 325, 1811-17.

Waite, L.J. (1995). Does marriage matter? Demography, 32, 483-508.

Waite, L.J. \& Gallagher, M. (2000). The case for marriage : why married people are happier, healthier, and better off financially. New York: Doubeday.

Weiss, Y.\& Willis, R.J. (1985). Children as collective goods in divorce settlements. Journal of Labor Economics, 3, 268-292.

White, L. (1994). Stepfamilies over the life course: social support. Paper presented at the National Symposium on Stepfamilies, Pennsylvania State University, PA. 
Table 1: Variable Definitions and Summary Statistics

Variable

Definition

Mean

\section{Dependent Variables}

Cash transfers

Time transfers

Living Arrangement a

\section{$=1$ if child gave parent $\geq \$ 500$ in past 2 years; 0 otherwise}

$=1$ if child gave parent ADL/IADL assistance in past 4 weeks; 0 otherwise

$=1$ if parent lives alone;

$=2$ if parent lives in nursing home;

$=3$ if parent lives with someone other than child;

$=4$ if parent lives with index child;

$=5$ if parent lives with other child
06

.08

\section{Parent's Marital Status and Marital History}

Divorced/Separated

Remarried
$=1$ if parent of child is separated or divorced; 0 otherwise

$=1$ if parent of child ever remarried; 0 otherwise
.09

\section{Child's Kin Relationship to Parent and Family Type}

\section{Step Child}

No siblings

Parent has at least one step child (exclusive of index child)

Parent has at least one biological child (exclusive of index child)
$=1$ if index child is a step child of the parent; 0 otherwise

$=1$ if child has no siblings; 0 otherwise

$=1$ if all other children (excluding index child) are step children of the parent

$=1$ if all other children (excluding index child) are biological children of the parent; 0 otherwise

$=1$ if sibling's network (excluding index child) includes both step and biological children; 0 otherwise
.06

.07

.10 


\section{Other Parent Characteristics}

Female

Black

Hispanic

Less Than High School Education

Some College

Disability Level: ADL1-2

Disability level: ADL3+

Age

Net Worth

Income

\section{Child Characteristics}

Female

Age

Less Than High School Education

Some College

Married

Child has no children

Number of Children

Child is Financially Worse than Parent

All Children are Financially Worse than Parent

Child and Parent are the Same Gender

Number of Siblings
$=1$ if parent is female; 0 otherwise $\quad .81$

$=1$ if parent is Black; 0 otherwise

$=1$ if parent is Hispanic; 0 otherwise $\quad .08$

$=1$ if parent is high school graduate; 0 otherwise $\quad .23$

$=1$ if parent attended college; 0 otherwise $\quad .16$

$=1$ if parent has 1 or 2 ADLs; 0 otherwise $\quad .41$

$=1$ if parent has 3 or more ADLs; 0 otherwise $\quad .30$

$\begin{array}{ll}=\text { parent's age divided by } 10 & 8.1\end{array}$

=parent's net worth divided by 10,000

=parent's non-bequeathable income divided by $10,000 \quad .25$

$=1$ if child is a daughter $\quad .51$

$=$ child's age divided by $10 \quad 5.2$

$=1$ if child is high school graduate; 0 otherwise $\quad .17$

$=1$ if child attended college; 0 otherwise $\quad .40$

$=1$ if child currently married; 0 otherwise $\quad .68$

$=1$ if child has no children; 0 otherwise $\quad .17$

=number of children of child for those with children $\quad 2.4$

$=1$ if child is financially worse off than parent; 0 otherwise $\quad .13$

$=1$ if all siblings of child are worse off than parent; 0 otherwise $\quad .34$

$=1$ if child and parent are the same gender; 0 otherwise $\quad .51$

$\begin{array}{ll}=\text { number of siblings of child } & 3.5\end{array}$

Note: All statistics are based on the sample of 4,863 children of unpartnered disabled elderly parents. 
Table 2: Cash and Time Transfers and Living Arrangements of Children, by Parent's Marital Status and Marital History, Child-Parent Relationship and Family Type

\begin{tabular}{|c|c|c|c|c|c|c|c|}
\hline & \multirow[b]{2}{*}{$\begin{array}{l}\text { Cash } \\
\text { Transfers }\end{array}$} & \multirow[b]{2}{*}{$\begin{array}{l}\text { Time } \\
\text { Transfers }\end{array}$} & \multicolumn{5}{|c|}{ Living Arrangement } \\
\hline & & & $\begin{array}{l}\text { Parent Lives } \\
\text { Alone }\end{array}$ & $\begin{array}{l}\text { Parent Lives } \\
\text { in Nursing } \\
\text { Home }\end{array}$ & $\begin{array}{l}\text { Parent Lives } \\
\text { with Others }\end{array}$ & $\begin{array}{l}\text { Parent Lives } \\
\text { with Index } \\
\text { Child }\end{array}$ & $\begin{array}{l}\text { Parent Lives } \\
\text { with Other } \\
\text { Child }\end{array}$ \\
\hline \multicolumn{8}{|c|}{ Parent's Marital Status and Marital History } \\
\hline Child's Parent is Widowed & 9.9 & $15.9 * * *$ & $60.2 * * *$ & $7.8 * *$ & 6.2 & $7.9 * * *$ & $18.1 * * *$ \\
\hline Child's Parent is Separated/Divorced & 11.7 & 11.4 & 65.9 & 9.8 & 7.8 & 4.5 & 11.9 \\
\hline Child's Parent Has Never Remarried & $14.0 * * *$ & 15.7 & 61.3 & $7.2 * *$ & 6.3 & 7.6 & 17.5 \\
\hline Child's Parent Has Remarried & 7.6 & 14.7 & 59.4 & 8.9 & 6.5 & 7.5 & 17.7 \\
\hline \multicolumn{8}{|l|}{ Relationship to Parent } \\
\hline Biological Child & $10.7 * * *$ & $16.1 * * *$ & $60.6^{* *}$ & $7.5 * *$ & 6.4 & $7.9 * * *$ & 17.5 \\
\hline Step Child & 2.7 & 4.6 & 63.6 & 10.6 & 6.7 & 1.8 & 17.2 \\
\hline \multicolumn{8}{|l|}{ Family Type } \\
\hline No Step Children Present in Family & $10.3 * *$ & $16.2 * * *$ & 60.2 & 7.6 & $6.3 \S$ & $7.9 * *$ & 17.6 \\
\hline Step Children Present in Family & 7.4 & 9.5 & 61.7 & 8.6 & 7.6 & 4.9 & 17.1 \\
\hline
\end{tabular}

Notes: Outcomes are percentages (the propensity to make a cash or time transfer and the distribution of living arrangement) Differences are statistically different from zero at $* * *(p<.05)$, ** $(0.5 \leq p<.10)$ and $\S(0.10 \leq p<0.15)$. 
Table 3: Estimated Bivariate Probit and Multinomial Logit Models of Transfers and Living Arrangement

\begin{tabular}{|c|c|c|c|c|c|c|}
\hline & \multirow[b]{2}{*}{$\begin{array}{c}\text { Cash } \\
\text { Transfers }\end{array}$} & \multirow[b]{2}{*}{$\begin{array}{c}\text { Time } \\
\text { Transfers }\end{array}$} & \multicolumn{3}{|c|}{ Living Arrangement } & \multirow[b]{2}{*}{$\begin{array}{c}\text { Parent } \\
\text { Lives } \\
\text { with } \\
\text { Other } \\
\text { Child }\end{array}$} \\
\hline & & & $\begin{array}{c}\text { Parent Lives } \\
\text { in Nursing } \\
\text { Home }\end{array}$ & $\begin{array}{l}\text { Parent Lives } \\
\text { with Others }\end{array}$ & $\begin{array}{c}\text { Parent } \\
\text { Lives } \\
\text { with } \\
\text { Index } \\
\text { Child }\end{array}$ & \\
\hline & & & $\begin{array}{r}\text { Relative Risk } \\
\text { Re }\end{array}$ & $\begin{array}{l}\text { ios (Parent Live } \\
\text { nce Category) }\end{array}$ & Alone is & \\
\hline \multicolumn{7}{|l|}{ Relationship \& Family Type } \\
\hline Index Child is Step Child & $\begin{array}{c}-0.83 * * * \\
(0.30)\end{array}$ & $\begin{array}{c}-0.88 * * * \\
(0.22)\end{array}$ & 0.96 & 0.71 & $0.10 * * *$ & 0.59 \\
\hline \multirow[t]{2}{*}{ (exclusive of index child) } & $\begin{array}{c}0.17 \\
(0.38)\end{array}$ & $\begin{array}{l}-0.11 \\
(0.28)\end{array}$ & 2.06 & 1.40 & 1.43 & $2.62 * *$ \\
\hline & $-0.18^{\S}$ & $-0.44 * * *$ & 1.36 & $0.55 * *$ & $0.65 * *$ & $12.9 * * *$ \\
\hline (exclusive of index child) & $\begin{array}{l}(0.11) \\
-0.08 \\
(0.40)\end{array}$ & $\begin{array}{c}(0.08) \\
0.09 \\
(0.31)\end{array}$ & 0.47 & 0.79 & 0.67 & $0.23 * * *$ \\
\hline Biological Child*Parent Has at Least One Step Child & $\begin{array}{l}-0.06 \\
(0.26)\end{array}$ & $\begin{array}{c}-0.08 * * * \\
(0.01)\end{array}$ & $.89 * *$ & 1.07 & $.90 * * *$ & $1.15 * * *$ \\
\hline \multicolumn{7}{|l|}{ Number of Siblings } \\
\hline \multicolumn{7}{|l|}{ Parental Marital Status \& History } \\
\hline Parent is Divorced & $\begin{array}{c}0.11 \\
(0.15)\end{array}$ & $\begin{array}{c}-0.23 * * * \\
(0.10)\end{array}$ & 1.27 & 1.17 & $0.46^{* * *}$ & $0.58^{\S}$ \\
\hline Parent was Ever Remarried & $\begin{array}{l}-0.15^{\S} \\
(0.09)\end{array}$ & $\begin{array}{c}0.02 \\
(0.06)\end{array}$ & 1.12 & 0.82 & 1.13 & 1.15 \\
\hline
\end{tabular}




\begin{tabular}{|c|c|c|c|c|c|c|}
\hline & \multirow[b]{2}{*}{$\begin{array}{c}\text { Cash } \\
\text { Transfers }\end{array}$} & \multirow[b]{2}{*}{$\begin{array}{c}\text { Time } \\
\text { Transfers }\end{array}$} & \multicolumn{3}{|c|}{ Living Arrangement } & \multirow[b]{2}{*}{$\begin{array}{c}\text { Parent } \\
\text { Lives } \\
\text { with } \\
\text { Other } \\
\text { Child }\end{array}$} \\
\hline & & & $\begin{array}{c}\text { Parent Lives } \\
\text { in Nursing } \\
\text { Home }\end{array}$ & $\begin{array}{l}\text { Parent Lives } \\
\text { with Others }\end{array}$ & $\begin{array}{c}\text { Parent } \\
\text { Lives } \\
\text { with } \\
\text { Index } \\
\text { Child }\end{array}$ & \\
\hline & & & $\begin{array}{r}\text { Relative Risk } \\
\text { Re }\end{array}$ & $\begin{array}{l}\text { ios (Parent Live } \\
\text { ence Category) }\end{array}$ & Alone is & \\
\hline \multicolumn{7}{|l|}{ Parental Characteristics } \\
\hline Parent is Female & $\begin{array}{c}0.17 \\
(0.15)\end{array}$ & $\begin{array}{c}0.10 \\
(0.08)\end{array}$ & 0.83 & $1.76^{\S}$ & $1.48 * *$ & 1.29 \\
\hline Parent is Black ${ }^{\mathrm{a}}$ & $\begin{array}{c}0.26 * * * \\
(0.12)\end{array}$ & $\begin{array}{c}0.03 \\
(0.07)\end{array}$ & 0.81 & $1.98 * * *$ & $1.76^{* * *}$ & $2.36^{* * *}$ \\
\hline Parent is Hispanic & $\begin{array}{c}0.06 \\
(0.17)\end{array}$ & $\begin{array}{l}-0.07 \\
(0.10)\end{array}$ & $\approx 0 * * *$ & 0.72 & $1.78 * *$ & 1.64 \\
\hline Parent Has Less Than High School Education ${ }^{b}$ & $\begin{array}{l}-0.12 \\
(0.13)\end{array}$ & $\begin{array}{l}0.11 * \\
(0.07)\end{array}$ & 1.12 & 1.53 & 1.08 & 1.02 \\
\hline Parent is College Graduate & $\begin{array}{l}-0.06 \\
(0.14)\end{array}$ & $\begin{array}{l}-0.12 \\
(0.09)\end{array}$ & 1.45 & 1.29 & 0.68 & 0.69 \\
\hline Parent has 1-2 ADLs ${ }^{\mathrm{c}}$ & $\begin{array}{l}-0.10 \\
(0.09)\end{array}$ & $\begin{array}{c}0.05 \\
(0.07)\end{array}$ & 1.58 & 1.27 & 0.93 & 1.10 \\
\hline Parent has $3+$ ADLs & $\begin{array}{l}-0.10 \\
(0.11)\end{array}$ & $\begin{array}{c}0.69 * * * \\
(0.07)\end{array}$ & $13.24 * * *$ & $2.52 * * *$ & 1.27 & $1.50 * *$ \\
\hline Parent's Age $(\div 10)$ & $\begin{array}{l}-0.04 \\
(0.07)\end{array}$ & $\begin{array}{c}0.29 * * * \\
(0.05)\end{array}$ & $2.45 * * *$ & 0.91 & $1.59 * * *$ & $1.30^{\S}$ \\
\hline Parent's Net Worth $(\div 10,000)$ & $\begin{array}{c}-0.01 * * * \\
(0.003)\end{array}$ & $\begin{array}{l}-0.002 \\
(0.002)\end{array}$ & $0.96 * * *$ & 0.99 & 1.00 & 0.99 \\
\hline Parent's Income $(\div 10,000)$ & $\begin{array}{l}-0.13 \\
(0.09)\end{array}$ & $\begin{array}{c}0.02 \\
(0.07)\end{array}$ & $0.65^{\S}$ & 1.07 & 1.04 & 0.85 \\
\hline
\end{tabular}




\begin{tabular}{|c|c|c|c|c|c|c|}
\hline & \multirow[b]{2}{*}{$\begin{array}{c}\text { Cash } \\
\text { Transfers }\end{array}$} & \multirow[b]{2}{*}{$\begin{array}{c}\text { Time } \\
\text { Transfers }\end{array}$} & \multicolumn{3}{|c|}{ Living Arrangement } & \multirow[b]{2}{*}{$\begin{array}{c}\text { Paren } \\
\text { Lives } \\
\text { with } \\
\text { Other } \\
\text { Child }\end{array}$} \\
\hline & & & $\begin{array}{c}\text { Parent Lives } \\
\text { in Nursing } \\
\text { Home }\end{array}$ & $\begin{array}{l}\text { Parent Lives } \\
\text { with Others }\end{array}$ & $\begin{array}{c}\text { Parent } \\
\text { Lives } \\
\text { with } \\
\text { Index } \\
\text { Child }\end{array}$ & \\
\hline & & & $\begin{array}{r}\text { Relative Risk } \\
\mathrm{Re}\end{array}$ & $\begin{array}{l}\text { ios (Parent Live } \\
\text { ence Category) }\end{array}$ & Alone is & \\
\hline \multicolumn{7}{|l|}{ Child Characteristics } \\
\hline Child is Female & $\begin{array}{l}-0.07 \\
(0.06)\end{array}$ & $\begin{array}{c}0.42 * * * \\
(0.07)\end{array}$ & 1.12 & $1.39 * * *$ & 0.79 & 0.95 \\
\hline Child's Age $(\div 10)$ & $\begin{array}{l}-0.02 \\
(0.04)\end{array}$ & $\begin{array}{c}-0.10 * * * \\
(0.03)\end{array}$ & 0.98 & 0.91 & $0.70 * * *$ & 0.94 \\
\hline Child has Less than High School Education ${ }^{\mathrm{b}}$ & $\begin{array}{l}-0.08 \\
(0.11)\end{array}$ & $\begin{array}{l}-0.03 \\
(0.07)\end{array}$ & 1.28 & $1.66 * * *$ & $1.42 * *$ & 1.19 \\
\hline Child is College Graduate & $\begin{array}{c}0.30 * * * \\
(0.07)\end{array}$ & $\begin{array}{l}-0.05 \\
(0.05)\end{array}$ & 0.91 & $0.64 * * *$ & 0.94 & 1.07 \\
\hline Child is Married & $\begin{array}{c}0.05 \\
(0.06)\end{array}$ & $\begin{array}{c}-0.09 * * \\
(0.05)\end{array}$ & 0.91 & 0.88 & $0.12 * * *$ & 0.95 \\
\hline Child Has No Children & $\begin{array}{c}0.07 \\
(0.09)\end{array}$ & $\begin{array}{c}0.03 \\
(0.08)\end{array}$ & 1.08 & $1.42^{\S}$ & $1.94 * * *$ & 1.19 \\
\hline \# of Children & $\begin{array}{l}-0.02 \\
(0.02)\end{array}$ & $\begin{array}{l}-0.03^{\S} \\
(0.02)\end{array}$ & 1.00 & 1.06 & .99 & 0.99 \\
\hline Child is Financially Worse than Parent & $\begin{array}{c}-0.35 * * * \\
(0.09)\end{array}$ & $\begin{array}{c}-0.24 * * \\
(0.09)\end{array}$ & 1.06 & 1.20 & $\approx 0 * * *$ & 1.03 \\
\hline $\begin{array}{l}\text { All Siblings are Financially Worse than } \\
\text { Parent }\end{array}$ & $\begin{array}{c}-0.27 * * * \\
(0.09)\end{array}$ & $\begin{array}{c}-0.10 * * \\
(0.06)\end{array}$ & 0.95 & 1.31 & $0.68 * * *$ & 0.92 \\
\hline Child and Parent are the Same Gender & $\begin{array}{c}0.01 \\
(0.07)\end{array}$ & $\begin{array}{c}0.08 \\
(0.06)\end{array}$ & $0.66 * * *$ & $0.72 * *$ & 1.26 & 0.97 \\
\hline Constant & $\begin{array}{l}-0.63 \\
(0.59)\end{array}$ & $\begin{array}{c}-2.70 * * * \\
(0.37)\end{array}$ & & & & \\
\hline$\rho$ & \multicolumn{2}{|c|}{$\begin{array}{l}.12 * * * \\
(0.04)\end{array}$} & & & & \\
\hline Log of the Likelihood & \multicolumn{2}{|c|}{$-3285 * * *$} & & $-4764 * * *$ & & \\
\hline
\end{tabular}


Coefficients are statistically different from zero at $* * *(p<.05), * *(0.5 \leq p<.10)$ and $\S(0.10 \leq p<0.15)$.

Reference category for race/ethnicity is other

Reference category for education is high school graduate

Reference category for disability is parent has only IADLs 


\begin{tabular}{|c|c|c|c|c|c|c|c|}
\hline & \multirow[b]{2}{*}{$\begin{array}{c}\text { Cash } \\
\text { Transfers }\end{array}$} & \multirow[b]{2}{*}{$\begin{array}{c}\text { Time } \\
\text { Transfers }\end{array}$} & \multicolumn{5}{|c|}{ Living Arrangement } \\
\hline & & & $\begin{array}{c}\text { Parent } \\
\text { Lives } \\
\text { Alone }\end{array}$ & $\begin{array}{c}\text { Parent } \\
\text { Lives in } \\
\text { Nursing } \\
\text { Home }\end{array}$ & $\begin{array}{c}\text { Parent } \\
\text { Lives with } \\
\text { Others }\end{array}$ & $\begin{array}{c}\text { Parent } \\
\text { Lives } \\
\text { with } \\
\text { Index } \\
\text { Child }\end{array}$ & $\begin{array}{c}\text { Parent } \\
\text { Lives } \\
\text { with } \\
\text { Other } \\
\text { Child }\end{array}$ \\
\hline Baseline Prediction & 9.4 & 15.4 & 60.7 & 7.7 & 6.4 & 7.6 & 17.5 \\
\hline \multicolumn{8}{|l|}{ Family Type and Relationship } \\
\hline A: Child is Biological and Has no Siblings & $13.5 \dagger \diamond$ & $26.0 \dagger \diamond$ & $67.4 \diamond \#$ & 6.5 & 12.3 & 12.0 & -- \\
\hline B: Child is Biological \& All Siblings are Biological Children & $9.6 \dagger$ & $15.1 \dagger$ & $60.0 \dagger$ & 7.7 & 6.0 & $7.5 \dagger$ & $18.8 b$ \\
\hline C: Child is Biological \& All Siblings are Only Step Children & $10.3 \square$ & $25.6 \dagger,+$ & $67.3 \diamond \#$ & $6.3 b \#$ & 13.7 & $11.6 \dagger$ & $1.0 \dagger, \dagger$ \\
\hline D: Child is Biological \& Siblings are Biological \& Step Children & $11.9 \dagger$ & $14.8 \dagger$ & $64.3 \diamond \#$ & $8.0 \#$ & 7.3 & $7.8 \triangle, \#$ & $12.5 \#$ \\
\hline E: Child is Step and Has no Siblings & 2.9 & 7.7 & $78.6 \# \nabla$ & 7.4 & 13.0 & 1.9 & -- \\
\hline F: Child is Step \& All Siblings are Biological Children & 1.9 & 3.5 & $70.9 \#$ & 8.7 & 5.4 & 1.1 & 13.9 \\
\hline G: Child is Step \& All Siblings are Step Children & 2.8 & $6.4 \#$ & $70.1 \#$ & 11.7 & 12.3 & 2.3 & $2.8 \#$ \\
\hline H: Child is Step \& Siblings are Biological \& Step Children & 3.4 & 2.8 & $55.1 \diamond \nabla$ & 12.2 & 6.3 & 1.1 & 26.1 \\
\hline
\end{tabular}

Notes: $\quad+$ denotes that category is significantly different than Rows E, F, G, and H at least at the $\mathrm{p}<.10$ level; $\mathbf{\square}$ denotes that category is different than Rows F, G at least at the $\mathrm{p}<.10$ level; $\ddagger$ denotes category is different than Row D at least at the p $<.10$ level; $\diamond$ denotes category is different than Row $\mathrm{E}$ at least at the $\mathrm{p}<.10$ level; $b$ denotes category is different than Row $\mathrm{G}$ at least at the $\mathrm{p}<.10$ level; \# denotes category is different than $\mathrm{H}$ at least at the $\mathrm{p}<.10$ level; $\triangle$ denotes category is different than $\mathrm{F}$ at least at the $\mathrm{p}<.10$ level. 